CSÁSzÁR Kinga

Doktorjelölt, PTE ÁJK

bíró, Budapesti IV. és XV. Kerületi Bíróság
DOI: 10.15170/DIKE.2018.02.02.06

\title{
A magyar nőmozgalmak erőfeszítései a leány és nőkereskedelem visszaszorítása érdekében a 20. század elején
}

\begin{abstract}
Efforts of the Hungarian Women's Movements to Reduce Woman and Child Trade at the Beginning of the 20th Century

By the middle of the 19th century, the social conflicts related to women's status became intense since female rights remained unsettled. Concomitant phenomena, such as the hopeless situation of the servants and the phenomenon of prostitution increased to an alarming extent. Although, people already realized in the 18th Century that venereal diseases affected the health negatively, the number of the prostitutes increased significantly in the second part of the 19th Century. In spite of the fact that the regulation concerning the subject was probibited early in the 19th Century, by the end of the Century, a whole industry developed around it. Not subject to question that white slave trade was the most dangerous crime among the ones linked with prostitution. Until 1908, the Hungarian Criminal Code did not order to punish this act at all and harlots were excluded from the protection provided by criminal law even after the modification of the law in 1908, because according to the actual public opinion, in the case of harlots, there were no values to defend. In the 20th Century, both women activists and the members of the International Agreement signed in Paris in 1910 were working hard to find a solution for the problem. It seems that the actual political power did not make any real efforts to change the situation and it stayed the same until the end of the studied era.
\end{abstract}

Keywords: female rights, servants, prostitution, woman trade, women's movements

\section{Bevezetés}

A prostitúció intézmény hazánkban erőteljesen jelen volt, különösen a 19. század második felében. A prostitúció, illetve annak kísérő jelenségei, amelyek közé a leány és nőkereskedelem tartozott, a részleges szabályozást kihasználva, sőt hosszú ideig a szabályozás teljes hiányában, megélhetési bűnözésként virágzott. A kapcsolódó bűncselekmények közül egyértelműen a leánykereskedelem bizonyult a legveszélyesebbnek a kiszolgáltatott helyzetben lévő, sokszor szegény sorsú nőkre nézve, amely a korlátozott hatékonyságú állami bűnüldözés következtében elképesztô méreteket öltött. Erre a problémára igyekezett megoldást találni az 1910. évi Párizsi Egyezmény, ahogy a magyar nőmozgalmi aktivisták is. ${ }^{1}$

\footnotetext{
${ }^{1}$ Lásd bővebben a szerzőnek a prostitúcióra, illetve annak kísérő jelenségeire vonatkozó dualizmus-kori magyar szabályozását bemutató tanulmányában. In: CsÁSzÁR, A kéjelgésügy 15-28.
} 
A kéjelgésügy szabályozása kapcsán kiemelendő, hogy a dualizmuskori Magyarországon a korszak nagy részében múködött ún. reglementációs rendszer a prostitúciót szükséges rossznak tekintette, azt megpróbálta korlátok közé szorítani. Elismerte ugyanakkor a létezését, hiszen a prostituált tevékenységének speciális zónákban szorításával egy lépést tett a legalitás felé. A szabályozás vagy éppen annak hiánya a Budapesten és az egyes megyékben megjelent szabályrendeletekben és a büntetőjogi kodifikáció eredményeiben (az 1795. évi és az 1843. évi tervezetben, az 1803. évi és 1852. évi osztrák büntető törvénykönyvben, valamint az 1878. évi V. tc-ben, az ún. Csemegi-kódexben), a prostitúció intézményével összefüggő törvényi tényállásokban megfigyelhető. Meg kell jegyezni, hogy a tárgykörben hatályos jogi normák gyakorlati érvényesülése sem volt egyértelmú. ${ }^{2}$

A prostitúció széles körű üldözése, bár a tradicionális keresztény értékekkel élesen szemben állt, csak a 16. században, az első nagy szifiliszjárvány dühöngése idején indult Európa-szerte. A 19. század elején ismét toleránsabb lett a megítélése, azonban korlátok közé szorítását közegészségügyi és közerkölcsi szempontból ekkor is elengedhetetlennek ítélték. Miután a 18. században megjelent reglementációs szabályok és a bordélyházak nem váltották be a hozzájuk füzött reményeket, a nőmozgalmak tűzték zászlajukra a prostitúcióban érintett nők hathatós támogatását, majd a 20. században nemzetközi egyezmények sora számolta fel ezt a megengedő, de egyben korlátozó rendszert. $^{3}$

\section{A prostitúció fogalma és megjelenése}

Lényegét tekintve megfelel a mai fogalomnak Ulpiánus meghatározása, mely szerint a prostitúció a nemi kapcsolatoknak az a módja, amelyet az üzletszerűség, az alkalmi jelleg és az érzelmi közömbösség jellemez. ${ }^{4}$ Az üzletszerű kéjelgés Babilonból vándorolt Szíriába, majd onnan Föníciába, Egyiptomba és Karthágóba. Állami bordélyházat először S zolón arkhon létesített i.e. 600 körül. Rómában a prostituáltak létszáma Traianus császár uralkodása idején (98-117) érte el csúcspontját, szintúgy a nemi betegségeké. ${ }^{5} \mathrm{~A}$ zsidó vallásjog a házasságon kívüli szeualitás minden formáját elítélte, így a prostitúciót tűzhalállal és megkövezéssel üldözte. ${ }^{6}$ A prostitúciót diadalútjában a keresztény világnézet átmenetileg megakasztotta ugyan ${ }^{7}$, azonban A 13. század első felétől ismét a toleráns felfogás került előtérbe, az üzletszerű kéjelgés problémáját sokkal inkább közegészségügyi, mint erkölcsi kérdésként értékelték. Az évszázados büntetőjogi szigor enyhülése leginkább a büntető praxisban nyilvánult meg: a közvélemény által el nem ítélt magatartásokat a bírák a törvénykezés során enyhébben büntették, elnéző ítélkezési gyakorlatuk pedig előkészítette a racionális polgári szabályozást. ${ }^{8}$

\footnotetext{
${ }^{2}$ A levéltári forrásközlést megköszönöm Récsei Balázs fölevéltárosnak. In: RÉCSEI, A kéjelgésügy (...) a dualizmus elsô felében 311-342., valamint RÉCSEI, A kéjelgésügy (...) a dualizmus második felében 177-210.

3 A tanulmány időkeretein túlmutató szabályozás-történethez lásd: MiKLóssY, A budapesti prostitúció 6-8.

${ }^{4}$ A római jog tehát nem tekintette prostituáltnak az egy vagy csak kevés számú férfival viszonyt folytató nőket, akik a nemi érintkezést nem nyilvánosan és nem válogatás nélkül űzték, még akkor sem, ha tettüket esetleg pénzszerzési szándék is motiválta.

${ }^{5}$ MiKLÓSSY, A budapesti prostitúció 9-12.

${ }^{6}$ Mózes II. 20.

${ }^{7}$ PAULER, Büntetőjogtan 124-126.

${ }^{8}$ MEZEY, Büntetőjog és szexualitás 1.
} 
Mint említettük, a 16. században dühöngött az első szifiliszjárvány Európában. A felfedezés, hogy a betegség első számú terjesztője a prostitúció, hozzájárult nagyobb arányú üldözéséhez, azonban csak a 18. század második felében tudatosodott, először francia területen, hogy a hatóságok elsődleges feladata a szervezett egészségügyi ellenőrzés és gyógykezelés. Ezért vélték megoldásnak a bordélyházak kiépítését Európa szerte. ${ }^{9}$

\section{A leánykereskedelemhez kapcsolódó büntetőjogi szabályozás hazánkban a Csemegi- kódex hatálybalépése előtt}

A 19. századi szabályozás megértéséhez nem tekinthetünk el az e cselekményre vonatkozó előzmények ismeretétől. II. József 1787. január 13-án kihirdetett Santio Criminalis Josephina nevű kódexe már tartalmazta azt a tételt, hogy csak az olyan jogellenes cselekmény minősült bűntettnek, amelyet ez a kódex ennek nyilvánított és a perben a bíró csak az előírt törvényi büntetést szabhatta ki, bár a modern büntetőjog e két alapvető elve nem Beccariának, hanem sokkal inkább Joseph von Sonnenfelsnek volt köszönhető a Habsburg dinasztia uralmi területén. ${ }^{10}$ Ebben a rendszerben a nemes már semmi privilégiumot nem élvezett. ${ }^{11}$ Más hatása is volt azonban II. József büntetőjogi kódexének: a korábbi jogfelfogás szerint a legsúlyosabb deliktumok az isteni felség megsértéséhez kapcsolódtak. Ezzel ellentétben a Santio Criminalis Josephina, a kor szellemének megfelelően, egészen más módon ítélte meg a vallási törvényekkel összefüggő jogsértéseket, így a házasságtörést is. ${ }^{12}$ Mint koraszülött jogszabály, e kódex életképtelennek bizonyult, 1804-ben Ausztriában hatályon kívül helyezték, Magyarországon pedig már II. Lipót uralkodása alatt visszatértünk a Praxis Criminalishoz. A szabadságharc bukása után felállított császári bíróságok eleinte az 1803-as osztrák büntetőtörvénykönyvet használták. 1852-ben pátens léptette hatályba nálunk is az új általános ausztriai büntető törvénykönyvet, amelynek érvényét a szorosabb értelemben vett Magyarországon az Országbírói Értekezlet megszüntette és módosításokkal ugyan, de behozta ismét a régi törvényeket és gyakorlatot. Így ismét meghonosította azon állapotot, amelyben a bíró bölcs belátása szerint ítélt, tehát bizonyos tekintetben a bíró és törvényhozó szerepét egyesítette. ${ }^{13}$

Az európai törvényhozások kezdettől fogva büntették a kerítést, vagyis mások törvényellenes nemi közösülésének szándékos elősegítését. A római jogban egyes szerzők szerint csak az üzletszerű eseteit büntették. ${ }^{14}$ A középkorban megkülönböztették az üzletként (lenocinium vulgare publ.) vagy csak egyes esetekben (lenocinium privatum), nyereményvágyból vagy más indokokból (lenocinium quaestuarium) illetve egyszerủen vagy minősítve (lenocinium simplex, qualificatum) elkövetett eseteit. A minősítést az érintettek személyes viszonyaiból, vagy a fajtalanság súlyából vonták le. A kor jogtudósai szerint a cselekmény súlyossága abból adódott, hogy általában a kerítő volt az elkövetés értelmi szerzője. A 18. században megjelent újabb törvényhozások, habár a

\footnotetext{
${ }^{9}$ MikLóssy, A budapesti prostitúció 9-14.

${ }^{10}$ Lásd bővebben OGRIS, Joseph von Sonnenfels 143-180.

11 HAjDU, Az első magyar büntetőkódex-tervezet 29-38.

12 HAJDU, Az első magyar büntetőkódex-tervezet 39.

13 LÖW, A magyar büntetőtörvénykönyv 7-12.

${ }^{14}$ A római jog még arra az esetre is kiterjesztette a kerítés tényállását, amikor utólagos pártolás esete merült fel (a férj a házasságtörésen tetten ért feleségét megtartja, vagy ilyen nőt feleségül vesz, ilyen cselekmény eltitkolásából nyereményt húz).
} 
házasságon kívüli nemi közösülésnek nem minden fajtáját büntették és ehhez képest a kerítés fogalmát hol tágabban, hol szűken értelmezték, nagyrészt mégis kriminalizálták e cselekményt. Természetesen, ha súlyosabb bűncselekmény is megvalósult, a cselekmény az utóbbi tényállás szerint volt büntetendő. ${ }^{15}$

A kerítés bűntettérôl a hazai törvényeink a Csemegi-kódex hatálybalépése előtt nem intézkedtek, a gyakorlatban a büntetése a bíró belátására volt bízva. Ugyan a legtöbb európai törvényhozás szerint a cselekményt férfiak és nők egyaránt elkövethették, azt a Sacrum Romanum Imperium szubszidiárius joghatállyal rendelkező első büntető törvénykönyve, a Constitutio Criminalis Carolina (1532) után a mi gyakorlatunk is csak a nőszemélyekre szorította. A bűncselekmény tárgyát csak „kiválólag nôke” képezhették és az elkövetési magatartás - amely lehetett tett vagy mulasztás - másoknak tilos nemi közösülésére alkalomszerzés, annak más nemû segélynyújtás által történő előmozdítása vagy könnyítése, akár történjen ez önhaszonlesésből, vagy más okból (barátság, bosszú). A Carolina és annak nyomán nyilvánvalóan a magyarországi ítélkezési gyakorlat is, az üzletszerű és minősített kerítést a bíró mérséklete szerint fenyítendőnek tartotta. ${ }^{16}$

A felvilágosodás korában legjelentősebben az erkölcsi bűntettek megítélése változott nagyon rövid idő alatt. Régebben, hazai törvényeink szerint a nemi ösztön tilos kielégítésének büntetése minden házasságon kívüli közösülés megbüntetését vonta maga után, és az ide tartozó bűntetteket összefoglaló néven delicta carnis (testi bủntett) nevezték. A carnalis delikutmok egy része a ,filozófusok" szemében az emberi gyengeségből adódott, ezért itélték meg másképp a házasságtörést is. Így a felvilágosítók már nem tartották büntetendő cselekménynek a paráználkodást (stuprumot), sokkal inkább elítélték azonban a kerítést két okból: egyrészt nem e menthető gyengeség, szenvedély ragadta az elkövetőt a tett elkövetésére, másrészt anyagi haszonszerzés célzata vezette a tettest más becsületének megrontására. ${ }^{17}$ Már ekkor felismerték a bűntett társadalmi okait, azt, hogy néhány társadalmi osztály nyomora, másrészt a krőzusi gazdagság mind oka ennek a deliktumnak, mint megélhetési búnözés létének.

Az 1795. évi magyar törvénytervezet (Codex de delictis eorumque poenis pro tribunalibus regni Hungariae partiumque eidem adnexarum per regnicolarem juridicam deputationem elaboratus) rendelkezett a nőrablás és a kerítés cselekményéről is. A nőrablás bűntette valamely nőnek, annak - vagy akiknek a nő a hatalma alatt állt - akarata és tudta ellenére, buja vágy kielégítése céljából való elhurcolása. A tervezet úgy rendelkezett, hogy a bűntett minőségét az elrabolt személy „rendi állapota és jelleme” szabta meg, sôt súlyosító körülményként értékelte, ha az elrabolt nő az elrablójától nagyon eltérő társadalmi helyzetben volt. A korabeli jogfelfogást tükrözte azon enyhítő körülmény, amely szerint enyhébb megítélés alá esett a tett, ha az elrabolt nőszemély „egyébként is tisztességtelen életet élt ${ }^{18} \mathrm{~A}$ törvénytervezet szerint kerítés volt minden olyan cselekedet, amely által valaki szándékosan elősegítette más tisztaságának prostitúcióját. Utóbbi törvényi tényállás is tartalmazta, hogy a bírónak mérlegelnie kell többek között a megrontott személy erkölcseit és társadalmi helyzetét. A deliktum büntetése gondatlan elkövetés esetében egy naptól három hónapig terjedő börtön, szándékos esetben három hónaptól egy teljes évig terjedő börtön lett volna a tervezet szerint, a

\footnotetext{
15PAULER, Büntetőjogtan 127-128.

16 PAULER, Büntetőjogtan 128-129.

${ }^{17}$ HAJDU, Az elsô magyar büntetőkódex-tervezet 346-348.

18 XXXVI. szakasz 1-8. §, lásd BALOGH, Die ungarische Strafrechtskodifikation 51-144.
} 
szégyenoszlopnál történő kipellengérezéssel és teljes kártalanítással együtt. Sajnálatos módon e büntető törvénytervezet nem emelkedett törvényerőre. ${ }^{19}$

A múvelt Európa elismerését is kivívó magyar 1843. évi büntető törvénykönyvi javaslat három évig terjedő rabsággal fenyítette a férjet vagy szülőt, aki feleségét vagy gyermekét bujasági célokra bérért vagy haszonért másnak szándékosan átadta. ${ }^{20}$

Az 1867. évi osztrák büntető törvénykönyv a kerítést rendszerint kihágásnak tekintette, illetve akkor tekintette bűntettnek, ha ártatlan személyt csábított el az elkövető, vagy ha a cselekményt felügyeleti jogkörét kihasználva (szülő, gyám, nevelő, tanító) követte el. Utóbbi esetben büntetése 1-5 évig terjedő súlyos börtön volt. E törvénykönyv szerint a kerítés kihágását azok követték el, akik kéjnőknek helyt adtak tilalmas üzletük folytatására, ilyen személyek elszerzésével üzérkedtek vagy más efféle tilos szövetkezésben közremúködtek. Büntetésük 3-6 hónapig terjedő szigorú fogság volt, amely súlyosbítandó, ha az üzlet hosszabb ideig folytatódott, visszaesés esetén pedig a bűnös kiutasítását is maga után vonta. A hazafiakat tartózkodási helyüktől, az idegeneket az egész birodalomból kiutasították. Ezen túlmenően kihágást követtek el a vendégfogadósok és kocsmárosok is, akik a fajtalanságra alkalmat szolgáltattak, büntetésük 25-200 forintnyi bírság, ismétlés esetén foglalkozásukból is elmozdíthatták őket. De még cselédjeik is, akik tudtuk nélkül elkövetők voltak, 8 naptól 3 hónapi fogságra számíthattak.

\section{A leánykereskedelemhez kapcsolódó büntetőjogi szabályozás hazánkban a Csemegi- kódexben}

A polgári büntető törvényhozás átértelmezte a nemi búncselekmény fogalmát. Ellenben a 17 . századig folytatott törvényszéki gyakorlattal, ${ }^{21}$ amelyben a tradicionális erkölcsfelfogásból fakadóan fontos helyet foglalt el a szexualitással kapcsolatos bűncselekmények szankcionálása, Csemegtervezete nem fektetett nagy hangsúlyt a szemérem elleni cselekményekre. Az újszerű felfogás, amely az 1878. évi V. tc-ben megjelent, a büntetendő cselekmény objektumát helyezte a középpontba és az előbbi cselekményeket, mint a szemérem megtámadásait büntette. Így az eredetileg erkölcs elleni bűncselekmények közé sorolt tényállásokat a személy elleni cselekmények közé helyezve a kódex XIV. fejezetében a szemérem elleni bűncselekmények közé sorolta az erőszakos nemi közösülést, a szemérem elleni erôszak és a megfertőztetés bűntettét, az erőszakos fajtalanságra kényszerítést, a 14 évesnél fiatalabb lánnyal történő közösülést, a természet elleni fajtalanságot (hasonnemúek és embernek állattal elkövetett testi érintkezését), a vérfertőztetést, a férjszínlelést, a házasságtörést, a csábítást (saját gyermekének kerítését), a szeméremsértő iratok, képek terjesztését, a szeméremsértő cselekmény általi közbotrányokozást és végül - az első büntetőnovellát (1908. évi XXXVI. tc.) követően - a kerítést és a leánykereskedést. ${ }^{22}$

Témánk szempontjából a fenti törvényi tényállások közül a csábítás majd kerítés szabályozása a legjelentősebb. A Csemegi-kódex a korábban a kerítés törvényi tényállásán belül szabályozott cselekményekre az 1908-as büntető novella hatályba lépéséig a csábítás törvényi

\footnotetext{
${ }^{19}$ XLIX. szakasz 1-4. \, lásd BALOGH, Die ungarische Strafrechtskodifikation 51-144.

${ }^{20}$ PAULER, Büntetőjogtan 129-130.

${ }^{21}$ Lásd bővebben: MEZEY, Magyar jogtörténet 246-247.

22 MEZEY, Büntetőjog és szexualitás 4.
} 
tényállását tartalmazta, amely annak valamennyi esetét nem helyezte büntetőjogi védelem alá, kizárólag nőnemú sértett sérelmére, és kizárólag a felügyeleti hatáskörben elkövetett eseteket bűntette, így az elkövető a szülő, gyám, gondok, nevelő, tanító vagy felügyelő lehetett. A Csemegikódex 247. \-ában a kerítés egy speciális esete, a csábítás elnevezéssel megfogalmazott tényállás első alakzata szerint öt évig terjedhető fegyházzal volt sújtható az a szülő, aki törvényes vagy természetes nőgyermekét mással nemi közösülésre, illetve törvényes vagy természetes gyermekét mással nemi, vagy természetelleni fajtalanság elkövetésére csábította. A tényállás második alakzata szerint ugyanígy volt büntetendő az is, aki a gyámságára, gondnokságára, nevelésére, tanítására vagy felügyeletére bízott személyt csábította ezen cselekményekre. Angyal Pál szerint a bűncselekmény jogi tárgya „a társadalom szexuálszociális értékrendjének normalitásához, másfelöl a sértett erkölcsiségéhez, testi fejlödéséhez és egészségébez, valamint a nemi életnek önelhatározásból való lebonyolitása szabadságához fürớdó érdek" volt. ${ }^{23} \mathrm{Az}$ elkövetési magatartás, vagyis a nemi közösülésre, illetve nemi vagy természet elleni fajtalanságra csábítás, Angyal szerint nem csupán rábírást jelentett, hanem minden olyan aktív magatartás beletartozott, amely a passzív alanyt az említett cselekmények végzésére motiválta. ${ }^{24} \mathrm{~A}$ Curia 89. számú döntvénye kimondta, hogy nem valósítotja meg a tényállást az, aki nem mással, hanem saját magával végzendő nemi cselekményre csábítotja a sértettet. ${ }^{25}$

Ugyan külön nem nevesítve, de tartalmazta a Csemegi-kódex a nőrablás tényállását is, mégpedig „a személyes szabadság megsértése magánszemélyek által' cím alatt szabályozott cselekmények között. Utóbbi tényállás szerint, aki fajtalanságra, vagy házasságkötésre irányzott célból valamely nőszemélyt annak akarata ellenére, erőszakkal, fenyegetéssel vagy ravaszsággal hatalmába kerített, elvitt vagy letartóztatott, öt évig terjedő fegyházzal volt büntetendő (a sértett fél indítványára amennyiben súlyos testi sértés nem valósult meg).

Az 1908-ban megjelent elsô büntetô novella ${ }^{26}$ a szemérem elleni búncselekmények közül a csábítás bűntettének meghatározásán változtatott: a továbbiakban kerítésnek nevezendő bűncselekmény törvényi tényállását jelentősen - mai meghatározását megalapozva - kibővítette, a lehetséges elkövetők körét kiszélesítette, és a felelősségre vonást szigorította. Kerítést az követett el, aki valamely, a 20. életévét be nem töltött „,tisżtességes nöt házasságon kivüli nemi közösülés vagy fajtalanság céjjára önérdekböl más részére szándékosan" megszerzett vagy erre törekedett (43. S). Ekkor a kerítés vétségi alakzata valósult meg. Amennyiben az elkövető valamely tisztességes nőt annak életkorától függetlenül szándékosan rábírt, hogy az előbbiekben említett célból bordélyházban, vagy más, ahhoz hasonló intézményben folytasson tevékenységet, ha a sértett nem töltötte be a 20 . életévét, az elkövető kerítés bủntettét, 20. életévét betöltött passzív alany esetében kerítés vétségét valósította meg. Ha a tettes ,valamely nöt bordélyházban vagy hasonló ü̃letben akarata ellenére bármely okboóp’ visszatartott, a kerítés bűntette valósult meg (44. S). A novella négy minősített esetet szabályozott, amelyek közül az erőszakos nemi deliktumok szempontjából azon eset fontos, amelynek értelmében a sértett korára és erkölcsiségére tekintet nélkül kerítés bűntettéért kellett felelősségre vonni azt, aki a kerítést erőszakkal, fenyegetéssel vagy csalárdsággal valósította meg. A büntetés a

\footnotetext{
23 ANGYAL, A magyar büntetőjog kézikönyve 123

24 ANGYAL, A magyar büntetőjog kézikönyve 146.

25 ANGYAL, A magyar büntetőjog kézikönyve148.

26 1908. évi XXXVI. tc.
} 
cselekmény minősítésétől függően fogházban, börtönben vagy fegyházban letöltendő, változó időtartamú szabadságvesztés volt.

Tehát a magyar büntető törvénykönyv egészen 1908-ig egyáltalán nem büntette a valós életben virágzó megélhetési bűnözést, a leánykereskedelmet. Egyedül egy 1869. évi miniszteri rendelet nyilvánította kihágásnak a fiatal nők külföldi bordélyba csábítását. ${ }^{27}$ (Talán ez is közrejátszott abban, hogy a külföldi nyilvánosházak lakói között sok ún. hungara volt). ${ }^{28} \mathrm{~A}$ kerítés büntetésének elmulasztását azzal indokolták, hogy magát a cselekményt nehéz bizonyítani, továbbá az áldozat is csak károsodik az ügy által. A kéjnő még az 1908-as módosítást követően is ki volt zárva a büntetőjogi védelemből, hiszen a kor felfogása szerint a kerítéssel előidézett erkölcsi bukás csak a tisztességes nőket sérthette, hiszen a kéjnők esetében hiányzott a védeni kívánt érték.

Márkus Dezsố, a korszakban ítélkező curiai bíró és jogtudós, a Nő és a társadalom című folyóirat hasábjain üdvözölte 1908 évben a büntető törvények módosításáról szóló törvényjavaslatot, amelynek a nőmozgalom szempontjából is nagy horderejű rendelkezései voltak. A szerző véleménye szerint a szentesítés alatt álló törvényjavaslat a leánykereskedés meggátolása érdekében tartott londoni és párizsi hivatalos konferencia (Gongrés international pour la repression de la traite des Blanches) határozatainak megfelelően szabályozta ezt a kérdést. Az első büntető novella 43. \-a csak az ún. tisztességes nőt oltalmazza, a bíróra bízva e fogalomnak esetről-esetre történő meghatározását. A curiai bíró álláspontja szerint azok, akik testükkel üzérkedtek természetesen nem vonhatók e fogalom körébe, de nem csak az tisztességes, aki nemi szempontból érintetlen. Kiemelte a szerző azt is, hogy a törvény nemcsak a húsz évnél fiatalabb leányt védte, hanem a húsz éven alul levő asszonyt is abból kiindulva, hogy a házasságkötés egymagában nem adja meg a testben és értelemben fejletlen nőnek azt az érettséget. Márkus Deaső́ megállapította, hogy a törvényhozó a büntetőjogi védelmet tágabb körre terjesztette ki, mint a hasonló tárgyú 1903. április 3-i francia törvény azzal, hogy a megszerzés szót a törvényhozó tudatosan használta. Ezzel a magyar törvény nem tartotta szükségesnek a büntethetőséghez sem a megtévesztést, sem az erőszakolást, még a nővel való közvetlen érintkezést sem kívánta meg. Üdvözölte, hogy a törvény 46. \3. bekezdése végre büntetni rendelte a külfölddel való leánykereskedést. ${ }^{29}$

\section{A prostitúciós tevékenység szabályozása 1880 és 1918 között, a kéjnők tevékenységének büntetőjogi megítélése}

A bujálkodás törvényi szabályozása a 19. századi törvényi jogunkból hiányzott, a Csemegi-kódex nem rendelte büntetni a prostitúciós tevékenységet. Tőlünk nyugatra az osztrák 1867. évi büntető törvénykönyv a helyi rendőrségre bízta büntetésüket, kivéve akkor, ha a kéjnő, aki a nyilvánosság számára feltűnő botrányt okozott, ifjakat csábított, vagy buja kórban tudva fajtalan üzletét folytatta. Ebben az esetben egytől három hónapig terjedő szigorú fogsággal fenyítette. ${ }^{30}$

\footnotetext{
${ }^{27}$ FINKEY, A magyar büntetőjog tankönyve 646.

28 MEZEY, Magyar jogtörténet 287-288.

${ }^{29}$ MÁRKUS, A nővédelme 134-135.

${ }^{30}$ PAULER, Büntetőjogtan 126-127.
} 
Az első prostitúciót érintő törvényünk a bujakor kezeléséről rendelkező közegészségügyi törvény volt 1876-ból, ${ }^{31}$ továbbá a kihágásokról szóló magyar büntető törvénykönyv kéjnőkre vonatkozó passzusa. ${ }^{32} \mathrm{Az}$ 1879. évi XL. tc., a kihágási Btk. 81. \-a úgy rendelkezett, hogy a „Kéjnők, a kike a reájuk vonatkozó hatósági szabályokat meg nem tartják: egy bónapig terjedhetó elzárással büntettetnek." A közegészségügy rendezéséról szóló 1876. évi XIV. tc. 91. \-a pedig kimondta, hogy „A kéjelgési ügy, amennyiben a közegészségre vonatkozik, rendeleti úton szabályoztatik." Ennek ellenére egészen 1926-ig nem született ilyen, a prostitúció rendészetét országosan szabályozó dokumentum. ${ }^{33}$

A szabályozás hiánya miatt a törvényhatóságok kénytelenek voltak saját területükön szabályrendeleteket alkotni. A helyi szabályrendeletek többnyire kiutasítással, közmunkára ítéléssel vagy testi fenyítéssel sújtották a tevékenységet végzőket. ${ }^{34}$ Schreiber Emil 1917-es monográfiájában arról számolt be, hogy „Egy városi és tizennyolc megyei törvényhatóság kivételével minden törvényhatóságnak van ilyen szabályrendelete". ${ }^{35}$

A közveszélyes munkakerülőkrôl szóló 1913. évi XXI. tc. bevezetett egy, a prostitúcióval összefüggő új bűncselekményt, a kitartottságot. A jogszabály 4. \2. pontja szerint vétségként volt büntetendő, aki kéjnővel vagy tiltott kéjelgésből élő nővel tartatta el magát. ${ }^{36}$ A belügyminiszter a 120.835/1913. B. M. sz. rendeletrel felhívta a törvényhatóságokat a kor követelményeinek megfelelő szabályok alkotására. A prostitúciós tevékenység országos szintű egységes szabályozásáról végül az 60.100/1926. B. M. sz. rendelet gondoskodott, amelynek nagy jelentőségű rendelkezése volt, hogy 1928. évi május l-jével megszüntette a bordélyházak múködését, és ezt követően már csak a magán- és nyilvános találkahelyek, illetőleg kéjnőtelepek engedélyezésére volt lehetőség. ${ }^{37}$ A korszakban megjelent szabályozás nem hozott érdemi eredményeket. Ennek legfőbb oka az volt, hogy amíg a nô gazdasági önállósága nem volt biztosított, a szabályok csak tüneti kezelést jelenthettek. $^{38}$

\section{A kéjelgésügy kezdeti szabályozása Pesten és Budán}

Városaink közül először Pesten és Budán alakult ki a prostitúció hagyományos értelemben vett intézménye. Az üzletszerű kéjelgés tolerálásának a szifilisz 16. századi járványszerű megjelenése vetett véget, amelynek következménye volt Mária Terézia intézkedése, aki 1765 után bezáratta az összes bordély Ausztriában, ${ }^{39}$ és ezzel együtt a hivatásos kéjnőket egyszerűen magyar területre „,hajóztatta”. A Wasserschub évente kétszer 150-300 főnyi rakománnyal érkezett 1752 és 1769 között. Még II. József, de uralkodása kezdetén I. Ferenc is rendészeti kérdésként kezelte a prostitúciót. ${ }^{40}$

\footnotetext{
31 A közegészségügy rendezéséről szóló 1876. évi XIV. tc. 89. 』

${ }^{32}$ Az 1879. évi XL. tc. 81. \- a szerint a kéjnők, akik a reájuk vonatkozó szabályokat nem tartják be, egy hónapig terjedő elzárással büntetendők.

33 160.100/1926. B.M. számú rendelet. In: BíRÓ, A prostitúció 3. In: GILÁNYI, A nők elleni erőszak 128-130.

34 PAULER, Büntetőjogtan 125.

35 SCHEIBEL, A prostitúció 67.

36 GILÁNYI, A nők elleni erőszak 136.

${ }^{37}$ A m. kir. belügyminiszter 1927. évi 160.100/1926. számú körrendelete, a prostitúció szabályozásáról. In: KÁNTÁs, Kérdőjelek a prostitúció körül 357., GILÁNYI, A nők elleni erőszak 130-132.

38 ZIMMERMANN, A magyar nőmozgalom 32.

${ }^{39}$ BÍRÓ, A prostitúció 46-47.

${ }^{40}$ MiKLÓssY, A budapesti prostitúció 17-21.
} 
Fontos megjegyezni, hogy az osztrák uralkodók a kéjnőkhöz hasonlóan büntették az erkölcstelen férfiakat is. ${ }^{41}$ 1816-ban a helytartótanács elrendelte, hogy Pesten a prostituáltakat kötelezzék munkavállalásra, visszaesés estén pedig az idegeneket toloncolják ki, a helybelieket közmunkával büntessék. Az 1848-ban a kereskedelmi minisztérium elrendelte egészségügyi ellenőrzésüket. ${ }^{42}$

A pest-budai prostitúció az 1848/49-es forradalom és szabadságharc vérbe fojtását követően fellendült, az önkényuralom 12 éve alatt virágkorát érte a korrupció és kiépült a nemzetközi szintủ leánykereskedelem. ${ }^{43}$ A prostituáltként megbélyegzett lányok és asszonyok jelentős része szegény volt és megélhetési problémával küzdött, amelyhez még hozzájárultak a lakásszerzés nehézségei is. A legtöbb prostituált az állástalan cselédek, munkanélküli munkáslányok és pincérnők közül került ki. A korabeli statisztikák is mutatták, hogy a szegénység sokkal inkább morális kérdésként merült fel, ha a nőkrôl volt szó, mint a nincstelen férfiak esetében. A fogházba zárt koldusok és csavargók csupán $20 \%$-a volt nő, míg a prostitúció miatt bezárt nőket is számításba véve ez az arány már 30-40 \% körüli. Végzetessé akkor váltak a női és férfi szegénység közötti megítélés következményei, amikor felismervén, hogy a munkanélküliség nem minden esetben lustaság vagy bűnözői hajlam következménye, a szegényeknek támogatásokat nyújtottak, amelyből a nők kívül rekedtek, őket ugyanúgy erkölcsileg bukottnak tekintették, mint korábban. ${ }^{44}$

A 19. század második felében Budapesten is köztudott volt, hogy az egyre elterjedtebb bujakor közösülés útján terjedt és annak legfőbb forrásai a kéjhölgyek voltak. Az egyre sürgetôbb szabályozás eredménye volt, hogy Pest város tanácsa 1867. október 30-án elfogadta a Bordélyházak és kéjhölgyek iránti szabályrendeletet (33.474/1867). ${ }^{45}$ Ezt sorra követtek a helyi rendeletek. A kor szelleme szerint a bordélyrendszer keretei közé kívánták szorítani a prostitúciót, azonban az ún. titkos prostitúciót meggátolni nem tudták.

Az átfogó szabályozás szerint a prostitúció egyetlen engedélyezett színtere a bordély lett, amelynek fenntartására türelmi bárcát kizárólag 30 év feletti nő kaphatott. Egy bordélyban legfeljebb 15 nő dolgozhatott, de a magánprostitúciós tevékenység kizárása érdekében a rendelet az alkalmazott kéjnők minimális számát (5 fö) is meghatározta, továbbá azt is előírta, hogy a házban az engedélyezett létszámon felül csak olyan cselédek dolgozhattak „kikeröl koruk és külsejüknél fogva feltehetó, hogy testükkel keresetet nem ü̃neke”. A bordélyok számának növekedését azzal igyekeztek gátolni, hogy a kávéházakban és mulatókban tiltott volt az alkohol tartalmú italok árusítása, sőt a hangos zene és mulatság is. Ugyan az 1867. évi rendelet szerint szigorú büntetés várt a 17. életévét be nem töltött leány alkalmazójára, 1909. évi módosítása már ezen szabály alól is kibúvót szolgáltatott azzal, hogy a fejlett és erkölcsileg már nem menthető leányok esetében kivételt tett. A prostituált minden negyedik napban köteles volt orvosi vizsgálatra jelentkezni, és csak az egészségügyi feltételeknek való megfelelés esetében kapott türelmi bárcát.

Az 1867. évi rendelet alapján összesen 40 nyilvánosház nyert működési engedélyt Budapesten, mégis nem egészen egy évtized múltán csak a VI., VII. és VIII. kerületben már jóval több volt a számuk ennél, és talán Európában nem volt egyetlen város sem, ahol a sokszor 12 év

\footnotetext{
${ }^{41}$ SCHREIBEL, A prostitúció 39.

42 DOROS, A prostitúció ellenőrzésének reformjáról 66.

${ }^{43}$ Miklóssy, A budapesti prostitúció 28-37.

44 SCHREIBEL, A prostitúció 106.

45 MikLÓsSY, A budapesti prostitúció 37.
} 
alatti prostituáltak száma nagyobb lett volna. A rendelet hibája volt, hogy a magánkéjnőkkel és az egészségügyi szempontból legnagyobb kockázatot jelentő ún. titkos prostitúcióval nem foglalkozott és nem tudott mit kezdeni az alkalmi prostitúcióval sem. Ennek is köszönhető, hogy 1877-re, tehát három év alatt 100 \% mértékben nőtt a szifiliszes megbetegedések nyilvántartott száma, amely nyilvánvalóan az orvosi ellenőrzéssel nem érintett titkos prostitúció eredménye volt. ${ }^{46}$

1884-ben a prostitúcióra vonatkozó új rendelet jelent meg Szabályrendelet a bordélyügyről (837/1884) címen, amely már szabályozta a magánkéjnôk múködését, engedélyezve e tevékenységet. A századfordulón megjelent az egészségi lap és a magánlakásban lévő találkahely intézménye, megjelentek az ún. diszkrét kéjnők és megmaradtak a hivatásosak és bordélyok lakói is. A súlypont a szabályozásban a rendőri ellenőrzés helyett áthelyeződött a betegek szűrésére, kezelésére és a megelőzésre. ${ }^{47}$

\section{A hiányos szabályozás társadalmi hatása a dualizmus korában}

A leánykereskedelem tényállásának törvényi hiánya számos sajnálatos következménnyel járt. Bár a magyarországi leányexport, mint üzlet már a török hódoltság idején nagyszabású volt és ugyanakkor Ausztria sem maradt el semmiben az ún. pogány mögött, Pest 1815 után lett a leánykereskedelem központja. A hungara kifejezés a történelmi Magyarországról érkezőt jelentette. A magyarországi leányexportnak a cári Oroszország is fontos helyszíne volt. A kibontakozott lánckereskedelem útján Temesvár és Brassó jelentették a hazai végállomást, ahonnan Szerbiába, illetve Romániába vezetett az út, később még távolabb. ${ }^{48} \mathrm{~A}$ magyar kéjhölgyek keresettek voltak világszerte. Így a Szuezicsatorna 1870-ben történt megnyitási ünnepségére nagyobb kontingens ún. fehér rabszolga (hungara), főleg magyarországi leány került önként (vagy kevésbé önként) Egyiptom bordélyaiba, háremeibe (ún. hungara-botrány). ${ }^{49}$ De a Közel- és Távol-Keleten, sôt Dél-Amerikában is nagy keletje volt a magyar nőknek. A belügyminisztérium számos alkalommal küldött figyelmeztető leiratot a törvényhatóságokhoz a kerítők múködésének meggátolására. Pestet az 1870-es évekre teljesen behálózta a leánykereskedők, felhajtók és kerítők serege. A rendőrségi archívumok hajmeresztő eseteket őriztek meg. A felhajtók előszeretettel álltak lesben a szülészeti klinikák előtt, hogy az elbocsátott leányanyák kiszolgáltatott helyzetét kihasználják. Hiszen őket 3-4 nappal a szülés után, legyengült állapotban az utcára tették. Ilyen helyzetben kezdeti tiltakozások ellenére legtöbbször elfogadták a külföldön felajánlott jól jövedelmező állást. Sőt, egyes források szerint, a szállítók sorában a rendőrség állt az első helyen. ${ }^{50}$

Még századunk elején is rendre utasította el a bíróság a ravasz csellel tôrbe csalt, megbecstelenített nők keresetét, a bukott nőnek hinni nem lehet szentenciával. A B. Berta családnevét még a források sem említették, ugyanis egy tekintélyes egyházfejedelem unokahúga volt. A szép és mûvelt Bertát mint egyetlen gyermeküket, a birtokigazgató édesapa, a főpap testvére és édesanyja gondosan nevelték, éppen történetünk idején tért haza egy neves drezdai leánynevelő

\footnotetext{
${ }^{46}$ MikLóssy, A budapesti prostitúció 52-54.

47 MikLÓssY, A budapesti prostitúció 65 .

${ }^{48}$ Miklóssy, A budapesti prostitúció 69-73.

${ }^{49}$ FORRAI, Részletek 83.

${ }^{50}$ MikLÓssY, A budapesti prostitúció 77-81.
} 
intézetből. Kiváló tanulmányi eredményeit jutalmazva, az 1870-es évek elején a család az egyik telet Pesten töltötte, hadd farsangolja ki magát eladósorba jutott gyermekük, akinek ez lett a veszte. A bájos teremtésre egy Pesten tartózkodó angol mérnök szemet vetett, azonban nem tudván a közelébe férkőzni, felkereste a város egy leghírhedtebb kerítőnőjét, $H$. Jucit. Az angol úr a kerítőnő szolgáltatásaiért 10.000 osztrák forintot fizetett és egyetlen kikötése az volt, hogy az akkori szokással ellentétben ne altassák el a kiszemelt lányt. Tíz nap sem telt el, és a mit sem sejtő hajadon már H. Juci lakásában tárgyalt, ördögi cseltôl elcsábítottan. Hiába próbált volna menekülni a bezárt házból, ott senki sem tartózkodott. Mikor felismerte helyzetét, elájult és magához térvén nem voltak kétségei a történtek felől. Egy uszályról a Dunába ugrott, de egy rendőr kimentette. H. Jucinak természetesen semmi baja nem lett, hiszen ő tisztességesen fizette a rá kirótt sápot Thaisz főkapitány hitvesének és a rendőrbiztosnak, és különben is, ki tanúsítja, hogy a panaszos erôszak áldozata lett, és nem nyereségvágyból tette, amit tett, amire a kerítőnőnek tanúi voltak. Bertát tehát egy leánykereskedő kezére adták, aki rögtön értékesítette egy bordélyban. Amikor a szülők végre értesültek róla, mi történt gyermekükkel, már késő volt, és tekintettel az egyházfő presztízsére, egy minisztériumi főtisztviselő tanácsára, halottként siratták el a lányukat. A hivatalnok tanácsát szavatolta a korabeli joggyakorlat. ${ }^{51}$

\section{A leány és nőkereskedelem és a prostitúció kapcsolata}

A 19-20. század fordulóján a prostitúció szoros kapcsolatban állt az emberkereskedelemmel, ugyanis szinte kizárólag prostitúciós célra irányuló nő és gyermekkereskedelemről lehetett beszélni a korszakban. ${ }^{52}$ Ahogy azt a fentebb kifejtettek alapján láttuk, e korszakban Magyarországon a prostitúció szabályozása vonatkozásában a reglementációs szemlélet érvényesült, amely a tevékenység végzését nem tiltotta, hanem igyekezett azt meghatározott keretek közé szorítani a közerkölcs és a közegészség védelme érdekében. A szabályozás előírta az ún. kéjnők regisztrációját és rendszeres erkölcsrendészeti, valamint orvosi felügyeletét. ${ }^{53}$ Nem volt a jelenségre vonatkozó önálló, átfogó jellegű törvény, de a rendeleti szintű szabályozás is részleges volt. ${ }^{54}$

A kerítésnek az 1880-ban hatályba lépett Csemegi-kódexben meghatározott, szűkre szabott büntetőjogi szankcionálása nem tette lehetôvé a leánykereskedelem elleni hatékony fellépést. Az első nemzetközi szerződés a témában 1904-ben köttetett, ez volt az ún. fehérkereskedés elleni megállapodás, amely a leánykereskedés ellenőrzését és megakadályozását célzó rendészeti intézkedéseket tartalmazott. Az egyezmény előírta, hogy a megtévesztéssel vagy erőszakkal megvalósított cselekmény elkövetői „kinyomoztassanak”, hogy minden tagállamban legyen olyan hatósági szerv, mely e kérdéssel foglalkozik. A megállapodást Magyarországon csak 1912-ben hirdették ki. ${ }^{55}$

Párizsban, 1910. május 10-én tizennégy tagállam vállalt kötelezettséget a leánykereskedelem bűncselekményként való büntetésére. A magyar országgyúlés a párizsi egyezmény rendelkezéseit az

\footnotetext{
51 MikLÓssy, A budapesti prostitúció 116-118.

${ }^{52}$ FEHÉR, Az emberkereskedelem 115.

53 SCHREIBEL, A prostitúció 57.

${ }^{54}$ SCHREIBEL, A prostitúció 67.

${ }^{55}$ International Agreement for the suppression of the „White Slave Traffic” (Paris, 18 May 1904). In: GILÁNYI, A nők elleni erőszak 126-154.
} 
1912. évi LXII. törvénycikkben emelte a törvény rangjára és az ún. fehér rabszolgaság ellen társadalmi téren is felvette a harcot. Ekkor alakult meg a Magyar Egyesület a Leánykereskedés Ellen is, melynek elnöke Prohásそka Ottokár püspök és Tisza István miniszterelnök lett. Radikális változás e téren azonban csak az első világháborút követően történt. ${ }^{56}$

Az 1910. évi Párizsi Egyezmény már büntetőjogi jellegű rendelkezéseket tartalmazott. Az 1. cikke úgy rendelkezett, hogy „Büntetni kell azt, a ki oly czélból, hogy mások szenvedélyeit kielégitse, kiskoru asszonyt vagy leányt, bárha beleegyezésével is, kéjelgés czéljára megkerit, magával visz vagy bázi köréböl eltávolit, még ha a büncselekmény tényálladékának egyes elemei különbözö országok területén valósultak is meg". Nagykorú nők esetében a büntetendő cselekmények köre szűkebb volt, csak abban az esetben kívánták kriminalizálni e magatartásokat, ha azokat az elkövető erőszakkal, fenyegetéssel, hatalommal való visszaéléssel vagy egyéb kényszer alkalmazásával tette (2. cikk). Kiskorúnak az Egyezmény alapján a huszadik életévét be nem töltött személyt kellett tekinteni. A nők bordélyház részére való értékesítését nem rendelte büntetni, és szintén nem rendelkezett arról, ha prostituáltat a bordélyházban akarata ellenére visszatartották.

1912. évi XLIX. törvénycikkhez füzött indokolás szerint a megállapodásban és az egyezményben foglaltaknak a hazai jogszabályok teljes mértékben megfeleltek. Valójában azonban az I. büntető novellát követő rendelkezések nem teljesítették valamennyi követelményt, mivel a 20 . életévüket be nem töltött személyek megszerzése alapesetben csak akkor volt büntethető, ha a nő tisztességesnek minősült, és a cselekményt önérdekből valósították meg.

1925-ben hirdették ki hazánkban a Genfben 1921-ben elfogadott, a nő- és gyermekkereskedelem tilalmáról szóló egyezményt. ${ }^{57}$ A részes tagállamok immár - az 1910. évi Párizsi Egyezmény 1. cikkében meghatározott magatartások tekintetében - a mindkét nemhez tartozó gyermeknek biztosítani kívánták a védelmet. A kiskorúság életkori határát ugyanakkor felemelte a 21. életévre. Az egyezményt kihirdető 1925. évi XIX. törvénycikk módosította az I. büntető novella kerítésre vonatkozó rendelkezéseit a nemzetközi követelménynek való megfelelés érdekében. Ennek értelmében a büntetőjogi védelmet kiterjesztették a férfiakra is. ${ }^{58}$

Témánk szempontjából a következő jelentős állomás 1935-ben következett, amikor kihirdetésre került Magyarországon a nagykorú nők sérelmére elkövetett emberkereskedelemmel szembeni fellépésről szóló 1933-as genfi egyezmény. ${ }^{59}$ Az egyezmény, amely kifejezetten a felnőtt nőkre vonatkozott, a nők prostitúció céljából történő külföldre szállítását kívánta akadályozni, és büntetni rendelte a sértett beleegyezésével történő nemzetközi nőkereskedelmet is. ${ }^{60}$

\section{A nőegyletek tevékenységének hatásai}

A 19-20. század fordulójára nemcsak Magyarországon, de nemzetközi színtéren is egyre több nőegylet alakult. 1888-ban Londonban alakult meg az International Council of Women

\footnotetext{
56 MikLóssy, A budapesti prostitúció 89.

${ }^{57}$ International Convention for the Suppression of the Traffic in Women and Children (Geneva, 30 September 1921) kihirdette az 1925. évi XIX. tc.

58 1925. évi XIX. tc. 2. \$

${ }^{59}$ International Convention for the Suppression of the Traffic in Women of Full Age (Geneva, 11 October 1933), kihirdette az 1935. évi XX. tc.

${ }^{60}$ FEHÉR, Prostitúció és emberkereskedelem 123.
} 
(ICW)(Nemzetközi Nőtanács), 1906-ban az International Woman Suffrage Alliance (IWSA) (Nők Nemzetközi Választójogi Szövetsége). Ez az időszak tekinthető a magyarországi nőmozgalmak működésének legintenzívebb és legeredményesebb időszakának. ${ }^{61}$ 1907-ben alapították a Nő és a Társadalom című folyóiratot, amelynek működtetésében alapvetô szerepe volt a korabeli feminista nőmozgalom egyik kiemelkedő alakjának, Bédy-Schwimmer Rózának. A folyóiratot egészen 1913-ig két egyesület, a Feministák Egyesülete és a Nőtisztviselők Országos Egyesülete mûködtette. ${ }^{62}$

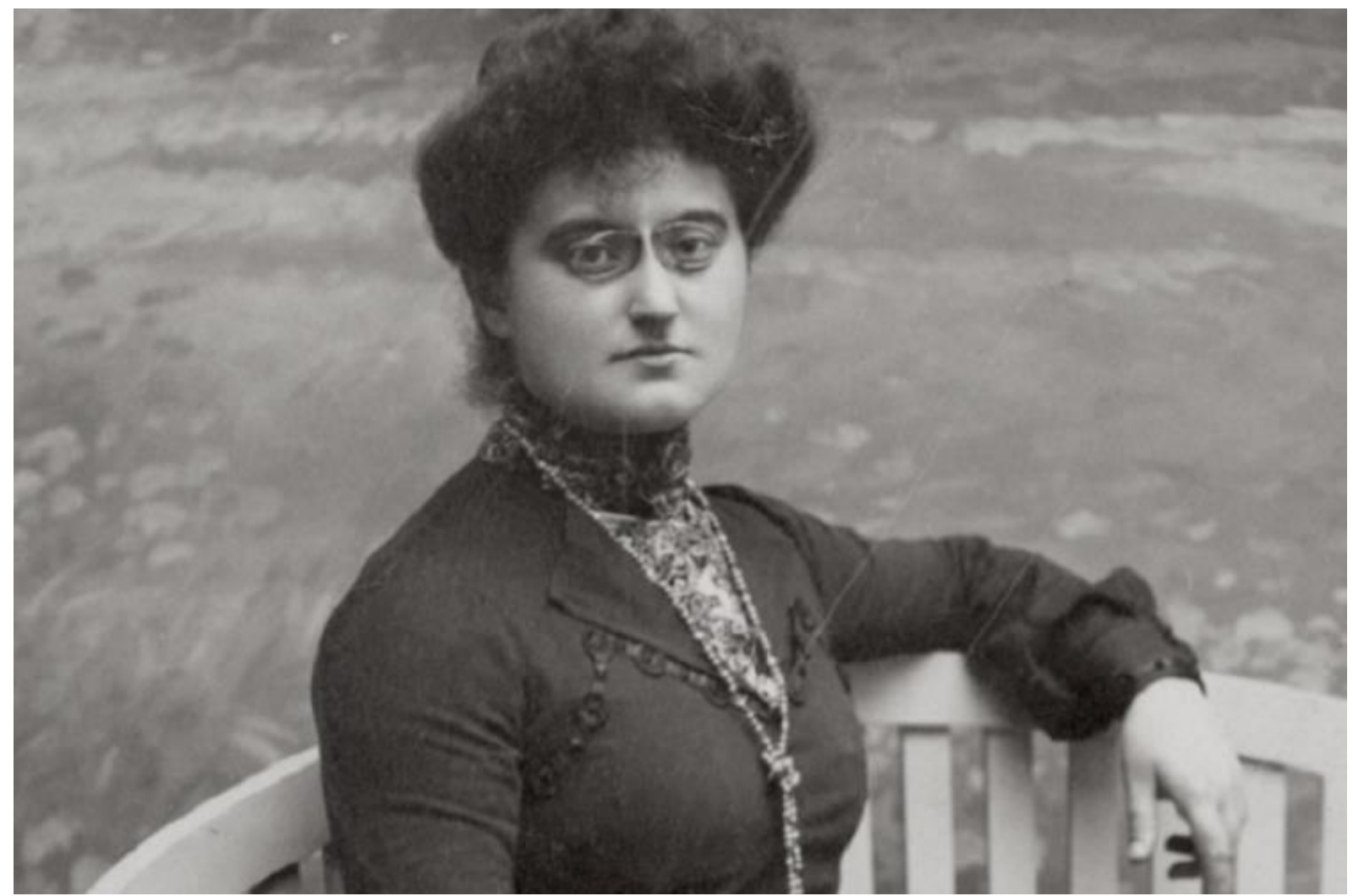

1. kép: Bédy-Schwimmer Róza $(1877-1949)^{63}$

Bédy-Schwimmer Róza a Nő és a Társadalom címú folyóiratban már 1907-ben hangsúlyozta, hogy a leánykereskedelem, az ún. hungara-export a prostitúció állami szabályozása, a kerítésről szóló törvény hiányainak, valamint annak is köszönhető, hogy a magyar szabályosan felajánlja, reklámozza a szép asszonyait a külföldi látogatók részére. „Amíg pedig szabályozott asszonytest-árulás leš, addig keresike az árút és amíg árút keresnek, addig lesž. ${ }^{64}$

1909-ben újabb rendelet látott napvilágot a Fővárosban, melynek fő célja a „titkos prostituáltak" elleni védekezés és a kéjnők kizsákmányolás elleni védelme volt. Ezek az intézkedések mind a nőegyesületek tevékenységének voltak köszönhetôk. A nőmozgalmak legfőbb eredménye az volt, hogy hivatalosan is lehetôvé tették a nőket védő közösségek és a rendőrség

\footnotetext{
${ }^{61}$ KÉRI, Hölgyek napernyővel 78-90.

62 Rosa Schwimmer Collection. New York Public Library Mss Col 6398. Életérôl lásd ZIMMERMaNN, A magyar nőmozgalom; idézi KERESZTY, A női szerepek tematizálása 187-197.

${ }^{63}$ https:// nokert.hu/tue-20140624-1902/646/504/bedy-schwimmer-rozsa-1877-1948-ujsagiro-feminista

${ }^{64}$ BÉDY-SCHWIMMER, A magyar asszony híre 40-41.
} 
együttmúködését. 1912-ben asszonyok pár fős csoportja kezdte meg munkáját a budapesti főkapitányság erkölcsrendészeti osztályán annak érdekében, hogy a regisztrációra jelentkezőket lebeszéljék a szándékukról. Még munkát és szállást is próbáltak szerezni nekik.

A századfordulón a nőmozgalmi aktivistákat nagymértékben foglalkoztatta a nagyvárosi prostitúció. Képviselői nem kívánták összetéveszteni a kéjelgés fölötti ellenőrzés megszüntetésének követelését a korlátlan szexuális piac létrejöttének elősegítésével, csak a prostituáltakkal, illetve az akként megbélyegzett személyekkel szembeni rendőri túlkapások ellen kívántak fellépni. ${ }^{65}$ A Magyar Nöegyesületek Szövetsége 1912-ben azt javasolta, hogy a regisztráció alsó korhatárát egységesen 18 évben határozzák meg. A szakirodalomban némelyek a 20. életévhez kötötték volna, de az életkor emelésére nem került sor. ${ }^{66}$

Hiába írtuk alá 1910-ben Párizsban a nemzetközi leánykereskedelem üldözéséről szóló egyezményt, 1914 nyarától a prostitúció ostorozása lekerült a lapok hasábjairól, egyrészt, mert a határ ôrizetét jobban megszigorították, másrészt mert a legális és illegális prostitúció az ún. megtűrt kategóriába került, ugyanis a hatalmasra duzzadt katonai létszám ezen intézmények fenntartását indokolttá tette. ${ }^{67}$ Ezen kívül a háborúban a prostitúció hatósági ellenőrzése is lehetetlenné vált. Schreiber Emil 1917-ben megjelent könyvében 105 törvényhatósági joggal felruházott, illetve rendezett tanáccsal bíró magyarországi város kéjelgésügyi statisztikájából adott ízelítőt. Budapest, mint világváros külön kategória volt. Ebben a több mint száz városban 1915-ben hivatalosan összesen 3.491 orvos-rendőri felügyelet alatt álló nôt tartottak nyilván. Közülük 2.296 fő dolgozott a felsorolt városokban mûköőő 261 bordélyházban, 294 fő magánkéjnőként tevékenykedett és 901 nek volt ún. tisztes munka vagy cselédkönyves foglalkozása, amely mellett folytatták az üzletszerű kéjelgést. Ezeken kívül kis és nagyközségekben további 228 bordélyházban 1.359 kéjnő állt a vendégek rendelkezésére, míg magánkéjnőként 258-an álltak nyilvántartás alatt.

Kaposvárt látta a lehetőségek városának egy szigetvári bordély tulajdonosa, mert itt akarta folytatni üzletét. Hegedús Lina éveken át Szigetváron múködtetett bordélyházat, de 1916-ban elhatározta, hogy Somogy székhelyvárosában próbál szerencsét, mert Pécs közelsége és az ott tapasztaltak új üzletpolitika és új helyszín kialakítására serkentették. Kaposvár pénztárába üzlete nyitása előtt négyszáz forint óvadékot tett be az új bordélyos. Az engedélyt Hegedüs Lina hamar megkapta, mivel ,fontos közegészségügyi érdeket képez, mert Kaposváron csak két kisebbszerü bordélyház van - e két ü̃let elégtelen”. Kisebb, hatóságilag elrendelt átalakítások után a Vár utca 17. szám alatt jött létre Hegedüs Lina saját bordélyháza, mellyel a „kényesebb įléseknek”” akart megfelelni. Weisz József és társai tiltakoztak az „erkölcstelenség mizériái" miatt, de miután a polgármester kiderítette, hogy az aláírásban szereplő társai mindössze két személyt takarnak, érdemben már nem is foglalkozott velük, mert az igazi közérdeknek a „titkos prostitúció minél kisebb térre” szorítását tartotta. A polgármester a jelek szerint nem igazán ismerte a prostitúció szerkezetét, ha egy elitnek szánt bordélyház megnyitásától remélte a titkos prostitúció visszaszorulását. Nyilvánvaló, hogy az építést engedélyező városi szakhatóság is tudta, hogy mi az ingatlan rendeltetése, mert a szomszédok

\footnotetext{
65 ZIMMERMANN, Nemiség, tisztesség és szegénység http://www.rubicon.hu/magyar/oldalak/nemiseg_tisztesseg_es_szegenyseg_a_nokkel_es_a_prostitucioval_kapcsola tos_vita_es_politika_becsben_e

${ }^{66}$ SCHREIBEL, A prostitúció 72.

${ }^{67}$ RÉCSEI, A kéjelgésügy (...) a dualizmus második felében 194.
} 
egyikének kérésére két méter magas, 28,5 m hosszú téglafallal kellett volna a telket bekerítenie a tulajdonosnak, amire azonban nem került sor, mert városi főmérnök, Berecそk Sándor által 1917. áprilisi árakon számított 2.307 koronányi beruházás meghaladta a tulajdonos lehetôségeit azért is, mert az alapanyagok egy részét a háborús viszonyok miatt lehetetlen volt beszerezni a fal építéséhez. ${ }^{68}$

\section{Következtetések}

Friederike Stelaner orvos 1912-ben előadást tartott a berlini Architektenhaus zsúfolásig megtelt nagytermében arról, hogy vannak-e született prostituáltak. A témával korábban csak két tudós foglalkozott behatóbban, a párizsi Parent-Duchatelet és Lombroso. Első a társadalmi szükségletet tartotta a prostitúció fő okozójának, míg Lombroso az ún. született prostituáltak tanát képviselte. Az előadó 12-21 éves prostituáltak vizsgálata alapján azt a következtetést vonta le, hogy a prostituáltak legnagyobb részét az abnormálisak, azaz a gyengeelméjủek és psychopatologikusuk szolgáltatták. Ennek ellenére azt állapította meg, hogy Lombroso született prostituáltja nem létezett, illetve nincs ilyen értelemben vett határozott anthropologiai típus, hanem a nyomorúságos viszonyok közt élő leányok ezrei endogén vagy exogén tényező következtében a normálisoknál, védetteknél, jó családban élőknél könnyebben esnek a zsákmányt leső szervezett prostitúció áldozatául. A törvényhozás feladata védő korlátokat állítani; az orvos feladata gyógyítani. ${ }^{69}$

Annak ellenére, vagy éppen annak köszönhetôen, hogy a 19. század elején a prostitúció szabályozása terén a tiltásé volt a főszerep, a század végére teljes iparág épült a bujálkodásra. Az 1860-as évektôl indult nagyarányú városiasodás társadalmi következményei elengedhetetlenné tették a szabályozást. Ezek a következmények vezettek az 1867. évi fóvárosi szabályrendelet kiadásához, amely részben legalizálta és így ellenőrzése alá vonta a jelenséget. A reglementációs rendszer azonban nem váltotta be a hozzá füzött reményeket. Az ellenőrzés nehézségei miatt a prostitúció titkos formái ugyanúgy múködtek, a tevékenység annak mindkét oldalán továbbra is megélhetési bűnözésként volt jelen. Nyilván kerítőként sokkal jövedelmezôbb volt, mint kéjnőként, nem beszélve arról, hogy a bordélyházak látogatóinak társadalmi megítélése korántsem volt olyan negatív, mint maguké a prostituáltaké.

A kéjelgéssel foglalkozó botránykrónikák, újságcikkek, tanulmányok, rendőrségi és szabályrendeletek hozzájárultak a női nemiséggel, a női tisztességgel kapcsolatos új szemléletmód elterjedéséhez. Azokról a női viselkedésformákról volt szó, különösen a kéjelgés ún. titkos megnyilvánulási formáiban, amelyek ellentétben álltak a korabeli elképzelésekkel arról, hogy miként kell a női nem tisztességes és erkölcsös képviselőjének a nyilvánosság előtt viselkednie. Ezzel éles ellentétben, a nőmozgalmi oldalt leszámítva egyetlen szemlélő sem foglalkozott azokkal a férfiúi magatartásformákkal, amelyek nélkül az üzletszerű prostitúció elképzelhetetlen lett volna. A legjobb esetben mellékesen megemlítették, hogy egyfajta természetes, éppen ezért semmiféle további magyarázatot nem igénylő szükségletről volt szó.

\footnotetext{
${ }^{68}$ SML Kaposvár polgármesteri hivatalának iratai 10346/1916. In: RÉCSEI, A kéjelgésügy (...) a dualizmus második felében 195.

${ }^{69}$ CREEL - LINDSEY, A nők választójoga a gyakorlatban 43-44.
} 
Máig eldöntetlen kérdés, hogy a prostitúció körüli morális-társadalmi törekvések, valamint a kormányzati jogpolitikai célzat mennyiben irányultak ténylegesen a probléma hathatós, gyakorlati megoldására. ${ }^{70}$ Míg Magyarországon az előírásokat áthágó ún. titkos prostituáltakra közbotrányokozás címén kirótt szankciók egy hónapnyi fogházbüntetésig terjedtek, addig Ausztriában 1885 után akár három hónapnyi fogházbüntetésre és bizonyos esetekben akár kényszermunkára is ítélhették őket. Az enyhe büntetési tételeken túl nem feledhető az sem, hogy a hatóságok a társadalom szükségleteire és a bordély tulajdonosoktól származó jelentős adóbevételekre hivatkozva gyakorta a szabálykövetés kikényszerítésétől is eltekintettek. Úgy tűnik, hogy a hatalom egészen eddig nem törekedett a prostitúció visszaszorítására, és ez a vizsgált korszak végéig így is maradt.

A Tanácsköztársaság hadat üzent a prostitúciónak, az azt igénybe vevő férfiak orvosi vizsgálatát egy 1927-ben megjelent belügyminiszteri rendelet (160.100/1926) tette lehetôvé, amely a bordélyházak múködését is megszüntette. Felismerték ugyanis, hogy a bordély-rendszer nem volt képes az üzletszerű kéjelgést más színterektől távol tartani. A második világháború után ismét virágzott a mesterség, és sajnos tetőzött a fiatalkorúak száma. A helyzetet rontotta, hogy a vidéki kapitányságokon nem múködött erkölcsrendészeti osztály, a titkos prostituáltak közel $80 \%$-a szenvedett fertőző betegségekben. 1947 után a titkos prostituáltak ellen, ha tetten érték őket, eljárást indítottak, a visszaesőket pedig szigorúan, szabadságvesztéssel büntették, sőt akik nemi betegségük ellenére végezték a tevékenységet, büntetőeljárás alá kerültek. A férfiak sem úszták meg, ha fertőző betegek voltak, egészségrontás címén kezdeményeztek ellenük eljárást. ${ }^{71}$

1950-ben, New York-ban aláírták az emberkereskedés és mások prostitúciója kihasználásának elnyomása tárgyában született nemzetközi egyezményt, amelyhez hazánk is csatlakozott. Az egyezmény 2. cikkelye tiltotta a bordélyházak fenntartását. Valóban nem találunk érvet a bordélyok fenntartása mellett, ugyanakkor rendkívül nehezen vonható szabályok közé az elszórtan múködő üzletszerű kéjelgés. A mai viszonyok közepette a nemi élet szabadsága és a nemi erkölcs elleni bűncselekményeket a Büntető Törvénykönyvről szóló 2012. évi C. törvény XIX. fejezete, az ún. maffia törvény, vagyis a szervezett bűnözés, valamint az azzal összefüggő egyes jelenségek elleni fellépés szabályairól szóló 1999. évi LXXV. törvény tartalmazza. A prostitúciós tevékenység szabályozása a szabálysértésekről szóló 2012. évi II. törvény tiltott prostitúcióra vonatkozó rendelkezése, önkormányzati rendeletek és a prostituáltak részére kiadandó orvosi igazolással kapcsolatban a fertőző betegségek és a járványok megelőzése érdekében szükséges járványügyi intézkedésekről szóló 18/1998. (VI. 3.) NM rendelet és az annak módosításáról szóló 3/2012. (I. 3.) NEFMI rendelet útján történik.

Végszóként álljanak itt Finkey Ferenc szavai: A felfogások ,leghelyesebb összeegyeztetése az, ba a kerités minden súlyosabb és erkölcsileg veszélyesebb esetét szigorúan bünteti az állam, a prostitúciót, a bordélyházakat a legszigorúbb hatósági és orvosi felügyelet és ellenörzés alá helyezi s igy gondoskodik, hogy a szomorú, de emberileg érthetô társadalmi betegség terén minden visszaélés meggátoltassék vagy sqigorian megtoroltassék s föleg lehetetlenné tétessék, hogy ártatlan serdülö lányokat lelketlen üzérek önzó anyagi érdekböl a bün és erkölcsi elsüllyedés posványába csábitsanak s a nôi test bájaival kereskedjenek."72

\footnotetext{
70 ZIMMERMANN, Nemiség, tisztesség és szegénység 3.

${ }^{71}$ Miklóssy, A budapesti prostitúció 67-68.

${ }^{72}$ FINKEY, A magyar büntetőjog tankönyve 600 .
} 


\section{Felhasznált irodalom}

ANGYAL Pál: A magyar büntetőjog kézikönyve 14. A szemérem elleni bűntettek és vétségek. Budapest 1937

BALOGH Elemér: Die ungarische Strafrechtskodifikation im 19. Jahrhundert. = VORMBAUM, Thomas (Hrsg.): Rechtsgeschichte und Rechsgeschehen. Band 12. Wien 2010

BÉDY-SCHWIMMER Rózsa: A magyar asszony híre. A nő és a társadalom 1907/3. sz. 40-41.

Bíró Béla: A prostitúció. A M. Kir. Rendőrség Országos Szaktanfolyamainak Kiadványa. Budapest 1933

CREEL, George - LINDSEY, Ben: A nők választójoga a gyakorlatban. Vannak-e született prostituáltak? In: A nő és a társadalom. 1912/3. sz. 43-44.

CSÁSzÁR Kinga: A kéjelgésügy szabályozása a dualizmus-kori Magyarországon különös tekintettel Somogyra. Jura 2012/1. sz. 15-28.

DOROs Gábor: A prostitúció ellenőrzésének reformjáról. In: Az országos közegészségi egyesület antivenerális bizottságának ünnepi kötete (1925-1935). Budapest 1935

FEHÉR Lenke: Az emberkereskedelem fogalmi megközelítésének néhány kérdése. In: LIGETI Katalin (szerk.): Wiener A. Imre ünnepi kötet. Budapest 2005

FEHÉR Lenke: Prostitúció és emberkereskedelem. In: NAGY Ildikó - PONGRÁCZ Tiborné (szerk.): Szerepváltozások. Jelentés a nők és férfiak helyzetéről 2009. Budapest 2009, 211-229.

FINKEY Ferenc: A magyar büntetőjog tankönyve. Budapest 1902

FORRAI Judit: Részletek a magyar leánykereskedelem és prostitúció történetéből. Egészségnevelés 1991/2. sz. 83-84.

GILÁNYI Eszter: A nők elleni erőszak és magyar büntetőjogi szabályozása a nemzetközi elvárások tükrében. PhD Értekezés 2017

HAjDU Lajos: Az első (1795-ös) magyar büntetőkódex-tervezet. Budapest 1971

KÁNTÁs Péter: Kérdőjelek a prostitúció körül. Magyar jog 1994/6. sz. 357-363.

KERESZTY Orsolya: A női szerepek tematizálása A Nő és a Társadalom címú folyóiratban (1907-1913). Új Pedagógiai Szemle 2012/9-10. sz. 187-197.

KÉRI Katalin: Hölgyek napernyővel. Nők a dualizmus kori Magyarországon 1867-1914. Pécs 2008

LÖW Tóbiás (szerk.): A magyar büntetőtörvénykönyv. A bűntettekről és vétségekről (1878: 5. tcz.) és teljes anyaggyűjteménye. I. kötet. Budapest 1880

MÁRKUS Dezső: A nővédelme a büntető novellában. A nő és a társadalom 1908/8. sz. 134-135.

MEZEY Barna: Büntetőjog és szexualitás Magyarországon. A nemi bűncselekmények megítélésének változásai (16-19. század). Rubicon 1998/7. sz. http://www.rubicon.hu/magyar/nyomtathato_verzio/buntetojog_es_szexualitas_ magyarorszagon_a_nemi_buncselekmenyek_megitelesenek_valtozasai/ (letöltve: 2018. 11. 11.)

MEZEY Barna (szerk.): Magyar jogtörténet. Budapest 1996

MiKLÓssY János: A budapesti prostitúció története. Budapest 1989

OGRIS, Werner: Joseph von Sonnenfels és az osztrák büntetőjog fejlődése. In: HERGER Csabáné - KAJTÁR István (szerk.) Európai jogtörténészportrék I. Budapest-Pécs 2007, 143-180.

PAULER Tivadar: Büntetőjogtan. Pest 1869

RÉCSEI Balázs: A kéjelgésügy szabályozása Somogy vármegyében a dualizmus első felében. In: Somogy megye múltjából. Levéltári évkönyv 30. Kaposvár 1999, 311-342.

RÉCSEI Balázs: A kéjelgésügy szabályozása Somogy vármegyében a dualizmus második felében. In: Somogy megye múltjából. Levéltári évkönyv 32. Kaposvár 2001, 177-210.

SCHREIBEL Emil: A prostitúció. Rendőrségi szaktanfolyamok Kiadmányai. Budapest 1917

ZIMMERMANN, Susan: A magyar nőmozgalom és a „szexuális kérdés” a XX. század elején. Eszmélet 1999/42. sz. 4966.

ZimmermanN, Susan: Nemiség, tisztesség és szegénység. A nőkkel és a prostitúcióval kapcsolatos vita és politika Bécsben és Budapesten a századfordulón. Rubicon 1998/6.

http://www.rubicon.hu/magyar/oldalak/nemiseg_tisztesseg_es_szegenyseg_a_nokkel_es_a_prostitucioval_kapcsola tos_vita_es_politika_becsben_e (letöltve: 2018.11.11.) 